\section{Past as prologue}

\author{
Ryan J. Huxtable
}

The Development of American Pharmacology: John J. Abel and the Shaping of a Discipline. By John Parascandola. John Hopkins University Press: 1992. Pp. 224. \$32.50, £27.

THE first citation in the Oxford English Dictionary for the word 'pharmacology' is dated to 1721 . It was more than 150 years, however, before anything approaching modern conceptions of the discipline arose out of the conjunction and transmutation of materia medica, physiology and chemistry. This chimaera of a book - part biography and part history of science - traces the path by which spores from the late victorian intellectual ferment in Europe were blown to the New World to seed the vigorous growth in pharmacology that we have seen this century.

The path was a strange one. Throughout the eighteenth and nineteenth centuries, Europe was abubble with provocative new findings. These ranged from the work of Scheele on oxygen in Sweden; Goethe's ultimately discredited ideas on colour and Sertümer's isolation of morphine in Germany; the multifaceted investigations of Pasteur in France of crystal forms and his refutation of abiogenesis; the toxicological experiments of Francesco Redi and Felice Fontana in Italy; and the self-dosing with nutmeg and belladonna of Purkinje in the part of the Austro-Hungarian Empire that later became Czechoslovakia. Yet pharmacology in the United States descends in a straight line from none of these countries, but from the remote and bleak littoral of the eastern Baltic. Here, in the fens of Estonia, is the town of Tartu, formerly Dorpat. And there at the university in the $1850 \mathrm{~s}$, the professor of materia medica was Rudolph Buchheim. Through his textbooks and students, he can be claimed as the father of German and the greatgrandfather of American pharmacology. He seems to have been the first to argue that pharmacology was a distinct discipline. One of his students was the Latvian, Oswald Schmiedeberg, co-founder in 1873 of the Naunyn-Schmiedeberg's Archives of Pharmacology, still in publication. Schmiedeberg left Dorpat to become professor of pharmacology at Strassburg, which was part of the German Reich from 1871 to 1918.

It was to Schmiedeberg's laboratory that the American, John Jacob Abel, came in 1886 , beginning a pilgrimage that became a sine qua non for American pharmacologists until well into this century. For a considerable period, ev- ery new chair of pharmacology in the United States was occupied by a student of Schmiedeberg. The influence he had in general is indicated by the fact that when he died in 1921, 40 chairs of pharmacology world-wide were occupied by his former students, a record that probably remains unbroken. Schmiedeberg, in continuation of the ideas of his mentor, distinguished materia medica, pharmacology and therapeutics, arguing that pharmacology provided the basis for the latter, but was a distinct discipline. His concept is enshrined in the name of the American Society for Pharmacology and Experimental Therapeutics, less formally known as ASPET

Abel returned to the United States, first to the University of Michigan, then to take the first chair of pharmacology in the country, at Johns Hopkins University in 1893 . He became the first president of ASPET and was the founder (in 1909) and first editor of the Journal of Pharmacology and Experimental Therapeutics. He also organized the American Society for Biological Chemistry and, with Christian Herter, helped to start the Journal of Biological Chemistry. At Johns Hopkins, Abel introduced laboratory work in pharmacology for medical students, one human demonstration being the effect of smoking on blood pressure. Such an approach was applauded in the Flexner report of 1910, which recommended that medical students should be exposed to laboratory work with animals in order to understand the experimental basis of therapeutics. Such exposure has now largely disappeared from the education of medical students, multiple-choice examinations having displaced laboratory work. Twenty years ago, students in my medical school had demonstrations on cats, dogs, frogs, guinea pigs, turtles and humans. Now only the latter species is used, in the emergency room on a Saturday night.

Another German tradition introduced by Abel has also disappeared. All his students were postdoctoral fellows. $\mathrm{He}$ opposed the awarding of doctorate degrees in pharmacology, believing that the ideal training for the aspiring pharmacologist was in chemistry and physics. So strong was the imprint of Abel on Johns Hopkins that it was not until 1969 that a $\mathrm{PhD}$ programme in pharmacology was established at the university. Now it is a rare pharmacology student who knows what happens when an acid is added to a base, or when sodium bicarbonate is heated. Students, however, have become adept at unwrapping molecular-biology kits.

Abel stressed the importance of daily get-togethers, where research problems could be discussed. Such gatherings were perhaps the most enjoyable and most educational part of my own training as a chemist. Again, however, this is a tradition that has vanished from modern departments with their entrepreneurial laboratories.

Desite these changes, American pharmacology, to a considerable degree, still reflects the traditions established by Abel. His view of science, and its essentially holistic nature, is expressed by his remark to Flexner: "The investigator is a man whose inner life is free in the best sense of the word. In short, there should be in research work a cultural character, an artistic quality, elements that give to painting, music and poetry their high place in the life of man."

It is ironic that in his own research Abel is probably best remembered for his studies on adrenaline (epinephrine). In fact, he mangled the isolation of this unstable and readily oxidized substance. His procedures included treatment of tissue with trichloracetic acid, and treatment of his extract with 25 per cent sulphuric acid or 15 per cent potassium hydroxide, procedures guaranteed to destroy substances more stable than a catechol. It is Jokichi Takamine who deserves most of the credit for establishing the structure of adrenaline.

It is important for pharmacologists to understand the roots of their discipline. Few do. But pharmacology, more than any other biomedical science, became what it is because of accidents of history. That is why the study of neurotransmitters is considered to be pharmacology rather than physiology, for example. If what's past is prologue, we must know the past in order to grasp the future. This is a period when pharmacology is under attack in the United States from parsimonious deans and curriculum comittees that consider that the absence of the words 'molecular' or 'neuro' from the name of a discipline relegates it to the dusty museum of science, along with Felice Fontana's wax models and the jars of pickled specimens. By understanding why and how pharmacology arose, we are better able to defend the contributions that this flexible discipline still has to make to biomedical research and teaching.

Ryan J. Huxtable is in the Department of Pharmacology, College of Medicine, University of Arizona, Tucson, Arizona 85724, USA.

\section{New Journals}

Nature's next review supplement is New Journals, which will appear in the issue of 7 October 1993. This annual survey will cover publications that first appeared during or after June 1991 and which issued at least four separate numbers by the end of April 1993. Further details will be given in next week's issue. 